gressional Fellowship Program's Advisory Committee. He replaces Thomas E. Mann, who had assumed leadership in late 1987. Ornstein is a former Congressional Fellow.

New members who recently accepted invitations to serve on the program's governing body include: Honorable Sam Brownback, U.S. House of Representatives; Richard E. Cohen, correspondent, National Journal; and Josette Shiner, managing editor, The Washington Times.

Representative Brownback was elected to Congress in November 1994 by voters of the second district of Kansas. A leader of the freshman Republican class, Brownback serves on the House Budget, International Relations and Small Business Committees. He practiced law in New York City in the 1980s and was secretary of the Kansas State Board of Agriculture from 1986 through 1993. As a White House Fellow in 1990-91, Representative Brownback worked for U.S. Trade Representative Carla Hills.

Richard Cohen's column, "Congressional Chronicle,' is featured regularly in National Journal, a publication for which he has written since 1973. Recently he has contributed feature articles to the Journal on Newt Gingrich and his House Republicans. For some readers, however, he is best known as the author of Washington at Work: Back Rooms and Clean Air, an accounting of the process that led to the passage of the Clean Air Act signed into law by President Bush in 1990. His next book will be a biography of former House Ways and Means Committee chairman Dan Rostenkowski, to be published by the Free Press. Cohen is a member of the Executive Committee of the Congressional Periodical Press Galleries.

A graduate of the University of Colorado, Josette Shiner has been a reporter and editor for two decades, and in 1992 was nominated for a Pulitzer Prize in international reporting. Active in many journalism organizations, she is editor of The American Editor, the monthly magazine of the American Society of Newspaper Editors, and is the recipient of an award from the International Consortium of Black Women in Business for hiring and developing African-American leaders in the field of journalism. In the Washington, D.C. community, Shiner has served on the United Negro College Fund's Washington advisory board, the Greater Washington Board of Trade's Special Task Force on Poverty, and as cochair of the Coalition for the Homeless annual fundraiser.

The 1996 Congressional Fellowship Program's Advisory Committee meeting was held May 1, at the Association's national headquarters.

\section{Annual Meeting Short Courses}

Each year in conjunction with the APSA Annual Meeting, the Association and the APSA Organized Sections offer a selection of short courses that include topics from the latest in high tech for the classroom to professional development. The courses provide an opportunity for members to enhance their knowledge about a field and to reinvigorate their teaching and research. The 1996 short course selection is below.

Short courses are scheduled for the day before the Annual Meeting on Wednesday, August 28. A registration form with complete times, costs and contact persons is located at the back of this issue of PS along with the preliminary program of the 1996 Annual Meeting. Preregistration by August 1 is strongly encouraged to ensure that appropriate course materials and reservations are prepared for you.

\section{Short Course 1: \\ The Leading Scholar Series}

The series is for graduate students and will focus on topics related to the professional life as a political scientist.
Short Course 2:

Asian Security Workshop

Sponsor: International Security and

Arms Control Section, in

collaboration with the Asia

Foundation

This day-long Asian Security Workshop will assess the new security environment of the post-Cold War Asia Pacific by focusing on the Korean peninsula's nuclear future; the relevance of Japan-US defense ties for regional stability; China as a pan-regional security actor; human rights and democratization in the Asian Pacific; and the creation of new security and economic regional mechanisms such as the ASEAN Regional Forum and the Asia-Pacific Economic Cooperation forum.

Conducted at the offices of the Asia Foundation, presenters will include Richard Ellings, National Bureau of Asian Research; Ed Olsen, Naval Postgraduate School; Richard Wilson, The Asia Foundation; Don Emmerson, University of Wisconsin; and Sheldon Simon, Arizona State University.

Short Course 3: Approaches to the Comparative Study of Gender and Policy Debates Sponsor: Organized Section on Women and Politics Research.

The goal of this full-day workshop is to bring together scholars from a variety of backgrounds to discuss how to study the inclusion of ideas about gender into public policy debates in post-industrial democracies. Changes in the policy process are central to increasing women's representation in democratic politics. Framing issues in gendered terms has the potential to bring groups and individuals who articulate women's needs into the process. At the same time, efforts to define issues in gendered terms, especially those that emphasize gender hierarchies may risk exclusion from the policy arena altogether. The workshop will explore the effects of gendering policy debates in democratic systems. Participants are welcome to bring ideas, methodological reflections, ongoing research or proposals for 
frameworks on analysis of gender ideas and policy debates.

\section{Short Course 4: \\ The Political Scientist as Pre-Law Advisor}

A mini-course designed to improve the skills of political scientists who find themselves responsible for pre-law advising. The sessions will examine the steps necessary to establish a successful pre-law program. Topics to be addressed will include: Getting Started: Identifying Students and Securing Resources; the Application Process; LSAC, LSAT and LSDAS: What the Letters Mean; Preparing for the LSAT: the Commercials and Do-It-Yourself; Ranking the Law Schools: Finding the

"Right" Law School for Your Students; Financial Aid Opportunities in the Nineties; Life After Law School?; and, the Role of Pre-Law Associations.

The course will be divided into a morning and afternoon session. The morning session will run from 9:30 A.M. to Noon; the afternoon session from 2 P.M. to 4 P.M. The sessions will be run at the Hastings College of Law of the University of California and The University of San Francisco Law School. A continental breakfast, luncheon and other refreshments will be provided.

Course coordinator will be Francis Graham Lee (Saint Joseph's University). Working with Dr. Lee will be: Thomas Brown (Saint Mary's College of California), Sally Derwaldt (University of WisconsinMilwaukee), Frank X.J. Homer (University of Scranton), Charles Neal (Western Maryland College), Beth Cobb O'Neil (Law School Admissions Services), Jerry Polinard (University of Texas Pan American), Gerald Wilson (Duke University), and Carol Wright (The Pennsylvania State University). Each of the course leaders has been involved either as officers in either their regional pre-law association or the Pre-Law Advisors National Coordinating Council.

The cost of registration for faculty is $\$ 45$; for graduate students, $\$ 20$. Participants will receive copies of the SAPLA Guide for Pre-Law
Advisors, the MAPLA Survey of Law Schools, The Official Guide to U.S. Law Schools, and LSAT test information packets.

\section{Short Course 5:}

The World Wide Web

Sponsor: Organized Section on

Computers and Multimedia

This morning session, led by Gary Klass of Illinois State University will be in two parts. The first will survey the Internet software applications used in browsing the World Wide Web and in creating and maintaining Web pages, such as Web browsers, plug-ins and helper applications and HTML editors. The programs will be shown on a Windows platform, although many of the applications are also available in MacIntosh format. We will also discuss how to get and install the software and how to configure the software for classrooms, laboratories and networks.

The second part of the morning session will address how to design Web pages for courses. We will examine some of the features of existing Internet-based political science courses, the kinds of materials and resources that can be provided to students on a course Web site and various interactive instructional applications.

Some basic familiarity with using Windows and/or Internet software is recommended. Registration fee $\$ 30$, enrollment limited to $10-20$ participants.

Further information can be obtained on the course Web site: http://www.ilstu.edu/ gmklass/ apsa96.

\section{Short Course 6: HyperText Markup Language Sponsor: Organized Section on Computers and Multimedia}

The two and one-half hour afternoon session, led by Bruce Neubauer of Wayne State College will include beginning and some intermediate instruction in actually writing home pages for the Web and other electronic documents in HTML. This session is recommended for those who want to prepare their academic writings (or other information) to be made available on the World Wide Web. The emphasis is on techniques rather than theory.

HTML "programming" is much more like word processing than computer programming in languages like Pascal or Fortran. The examples shown will be in a Windows platform. The process is very similar in a MacIntosh format. Users who already use word processing software will be able to create and edit HTML documents upon completion of the afternoon workshop. Use of more advanced options in HTML will, of course, require reference to one or more of the many books which are available on the subject.

The afternoon session will include the following topics. We will study how to design and organize sets of pages in hypertext documents (including home pages) so as to facilitate information access by people who read the documents. We will then survey some of the available tools including HTML browsers, editors, and converters. We will see how to view the HTML source code behind the home pages already on the World Wide Web, and how to copy that code to use as a template or example. HTML source code can also be edited in Microsoft Notepad (which comes with Windows) if only minor revision of the document (or page) is required.

Persons enrolled in the afternoon session will learn how to create hypertext links between parts of one document, between two or more of their own Web pages, and links to external sites on the World Wide Web. The basics of creating forms and including images (scanned photographs, Excel charts, and the like) will be discussed.

If time permits, some additional ways to use Netscape and HTML documents in creative ways will be discussed. For example, it is possible to create tables in Microsoft Access in such a way that a query can produce a dynaset which can be read to a .txt file which can be viewed in Netscape. If the table contains the addresses of Web sites or other electronic documents in HTML, the dynaset can provide 
the user with immediate access to that information through hot links to those files and/or sites. Registration fee $\$ 30$, enrollment limited to 10-20 participants.

\section{Short Course 7:}

National Issues Forums in the Classroom: A Deliberative Model for Teaching The Politics of Citizen Participation

Sponsor: National Issues Forums (NIF) on Campus Network

This course, in workshop format is designed to demonstrate the workings of National Issues Forums (NIF) as a collaborative classroom exercise and college and community activity for involving students in day-to-day politics. The course will include (a) discussion on the theory of deliberative politics and how it differs from conventional, adversarial models (b) presentation of recent books and other publications concerning the NIF and similar approaches, (c) practice in use of key tools/exercises that can be used in the classroom and (d) demonstration of the use of the NIF process for issue analysis and community problem solving.

The course will be taught by a team of professors and NIF practitioners with experience in both classroom and community application of NIF. Reference materials will include books such as Politics for People, David Mathews; Coming to Public Judgement, Daniel Yankolovitch; and Public Politics, Bob McKenzie. Also included will be studies by the Harwood Group such as College Students Talk Politics and Citizens and Politics as well as current NIF issue books, handbooks and manuals for use in the process.

\section{Short Course 8: \\ Requisites for Survival of Constitutional Democracy Sponsor: Committee on Viable Constitutionalism}

The short course on Requisites for the Survival of Constitutional Democracy will focus on the basic conditions, both institutional and non-institutional, which enable constitutional democracies to flourish and survive-the experience of the United States and other countries will be taken into account. Because non-institutional factors have received much more attention in the current literature, ${ }^{1}$ priority will be given to the institutional factors in the first of what, hopefully, will become an annual exercise-more attention can be given to the noninstitutional factors in follow-up sessions.

The core institutional factors include relationships between the legislature and chief executive, ${ }^{2}$ the electoral, party and nominating systems, rules affecting who can or must vote, courts, bureaucracies, the military, and unitary/federal/ confederal distributions of sovereignty. Among the non-institutional factors, consideration must be given to economic levels and changes, ethnic and class cleavages, cultural and religious practices, the role of the mass media, private organizations (both for profit and nonprofit), the composition of elites and ruling groups, etc. In the increasingly interdependent world system, the impact of external and internal state and non-state structures, financial and trade matters, etc. all deserve attention. Since everything cannot be examined in an opening course, top priority will be assigned to key institutional arrangements as a focus for the first Short Course organized by the Committee on Viable Constitutionalism.

Participants include Fred W. Riggs, University of Hawaii, as organizer, supported by a group of concerned members who are exchanging views via e-mail in prepa-

\footnotetext{
1 A recent article by Adam Przorski and others in the Journal of Democracy stresses non-institutional factors (especially economic level) that affect the survival of democratic regimes. However, they also prove, statistically, that parliamentary constitutional systems usually last longer than presidential ones.

2 An essay by Fred Riggs shows that virtually all (about 30) presidential regimes have experienced catastrophic breakdowns leaving the U.S. as the only important exception, and explains some of the institutional differences that seem to account for this fact. "Presidentialism in Comparative Perspective." Comparing Nations, ed. by Mattei Dogan and Ali Kazancigil. Blackwell, 1994.
}

ration for the course. They include Arend Lijphart, APSA president, Joel Aberbach, Abdo Baaklilni, Jorge Bela, Ali Farazmand, Ferrel Headfy, Gabriela Ilonski, Petr Kopecky, Jean Laponce, Shaheen Mozaffar, Bert Rockman, and Krishna Tummala.

\section{Short Course 9: \\ Waiting for Washington: How Sacramento Is Responding Sponsor: Organized Section on Federalism and Intergovernmental Relations}

The Federal budget stalemate and the uncertainties about the block grant and Medicaid funding have complicated other unresolved intergovernmental issues in California-among them, Governor Wilson's realignment initiatives on state/county responsibilities and funding, the California Constitutional Revision Commission's proposals, court challenges to immigration related expenditures, and even political careers. The states in 1996 are different players than they were in 1981, and so the void created by federal inaction may have also generated a patchwork of assertive policy responses which will consider options for the feds.

How has California exploited the opportunity to design policy alternatives? Have California's choices closed doors for the federal government? What will the patchwork of state responses look like?

This half-day course led by Christie Jensen, California State University-Sacramento, will consider the Sacramento response from legislative, state agency, and local government perspectives.

\section{Short Course 10: \\ Examining New and Existing Data Bases in Public Law: The U.S. Courts of Appeals, the Supreme Court, and State Supreme Courts Sponsor: Organized Section on Law and Courts}

This half-day short course is intended to help participants become more familiar with several rich data bases that are now, or soon will be, available to all scholars in the law and courts community. A primary 
focus will be on the newly released Appeals Court Data Base that should be available through the ICPSR by the beginning of the APSA Meeting. Also covered in the course will be explanations of recently added features of the Spaeth Supreme Court Data Base, including a discussion of the interface between the Appeals Court Data

Base and the Supreme Court Data Base. Rounding out the presentations will be a first look at the beginning phases of the creation of a state supreme court data base that has recently been funded by the National Science Foundation.

The workshop sessions will begin with overviews of the nature and design of the three data bases. We will then proceed to present a "user's guide" to the data bases. Since the Appeals Court Data Base is likely to still be unknown to most participants, its contents will be examined in greatest detail. Brief overviews of each of the three data bases and detailed codebooks for the Appeals Court and Supreme Court data bases will be available to participants. Details for obtaining copies of each of the data bases through the ICPSR will also be available.

Following a description of the contents of the data bases, potential uses of the data bases will be explored. A roundtable discussion featuring Susan Haire, University of Georgia, Ashlyn Kuersten, University of South Carolina, and Reggie Sheehan and Malia Reddick of Michigan State will present a first set of analyses of change over time on the courts of appeals. Three specific analyses will be presented: 1) Susan Haire, "Issue Evolution on the Courts of Appeals: A Longitudinal Analysis"; 2) Ashlyn Kuersten, "Changing Influences on Decision Making in the U.S. Courts of Appeals"; and 3) Reginald Sheehan and Malia Reddick, "The Changing Nature of Litigants in the U.S. Courts of Appeals." Departing from the normal format of convention papers, each panelist will briefly describe the research question that they are seeking to answer and then describe the details of the manner in which the Appeals Court Data Base was used to investigate their question. The emphasis will be on providing several "nuts and bolts" illustrations on the use of the data base. The presentations will conclude with a summary of the results of their analyses to date and ideas of future directions for research made possible by the availability of the data base.

The course will conclude with a roundtable on future directions for research and how the availability of these large data bases can contribute to a broadening of our scope of inquiry. Particular attention will be given to the types of projects that have already built on the Supreme Court Data Base, the ways in which the Appeals Court and Supreme Court Data Bases can be merged, and the potential for these data bases in graduate education. Tentative panel members for this roundtable are: Don Songer, University of South Carolina; Harold Spaeth, Michigan State University; Melinda Gann Hall, University of Wisconsin-Milwaukee; and Greg Caldeira, Ohio State University.

\section{Short Course 11:}

Business and Politics in America: Perspectives and Historical Patterns Sponsor: Organized Section on Politics and History

The purpose of this course is to review approaches to the study of business-government relations and business power in America from both contemporary and historical perspectives. It will examine the long-standing and continuing debate over the power of business in America, changes in the form and extent of business political activity, the role of business in shaping health-care policy, tax policy and environmental policy, changing corporate perceptions of economic growth, the business collective action problem, potential cross-class coalitions in the post-industrial welfare state, the historical development of business ideology, and the distinctiveness of American business-government relations.

This full day course will be led by David Vogel, University of California at Berkeley, and Cathie Jo Martin, Boston University.

\section{Foreign Student Travel Grants for 1996 APSA Annual Meeting}

The American Political Science Association will again offer a limited number of travel grants for foreign graduate students studying in the U.S. to attend the APSA Annual Meeting in 1996. Through funding support from the Huang Hsing Foundation and members of the APSA, the Advanced Foreign Graduate Student Travel Grant Program will bring nearly 30 foreign students to Chicago.

APSA selects the recipients on the basis of the following guidelines:

- Recipients of awards must be studying in the United States at the time the award is offered to them.

- Recipients must be full-time graduate students. Foreign graduate students having refugee, immigrant, or tourist visa status are not eligible.

- Applicants who are furthest along in their graduate course of study and intend to return to their native country once their course of study is completed will be given preference.

- Applicants are not eligible for awards if they are receiving any U.S. government funds for either travel or academic expenses.

- Previous grant recipients are not eligible.

- The maximum award to an individual is $\$ 300$.

Applicants must complete a form available from the APSA national office and must have their department chair write a letter of support for their application. Applicants without a letter of support will not be considered.

The deadline for the receipt of the complete application for a travel grant to the August 28-September 1, 1996 Annual Meeting is July 5. Application forms and further information are available by calling (202) 483-2512 or e-mail twombly@apsa.com. 